\title{
Pengembangan instrumen kualitas layanan dosen universitas swasta menggunakan pemodelan Rasch
}

\author{
Yuyun Elizabeth Patras ${ }^{1}$, Rais Hidayat ${ }^{2}$ \\ ${ }^{12}$ Universitas Pakuan, Indonesia
}

\begin{tabular}{|c|c|}
\hline Article Info & ABSTRACT \\
\hline Article history: & This research aims to get a research instrument, namely quality service \\
\hline Received Des 18th, 2019 & lecturer at private university. The research method used mixed methods \\
\hline Revised Jan 21st, 2020 & consists of literature reviews, interviews with students, expert validation, and a \\
\hline Accepted Feb 1st, 2020 & test use Rasch modeling. Literature review is carried out to obtain a \\
\hline & Interviews with students aim to obtain items of review that fit the research \\
\hline Keyword: & context. Expert validation aims to obtain content validity. Collecting data \\
\hline Private university & through a questionnaire instrument containing 32 items. The number of \\
\hline Rasch model & respondents was 543 students at Pakuan University. The finding that 31 items \\
\hline Service quality & $\begin{array}{l}\text { of valid lecturer service quality instrument and one (1) item that is invalid } \\
\text { must be discarded; This lecturer service quality instrument is very reliable } \\
\text { because it has a reliability value above } 0.9 \text {, both in terms of people reliability, } \\
\text { alpha cronbach and item reliability. However, based on the item difficulty } \\
\text { level test using item measure, item dimensionality and variable map, and } \\
\text { Item: DIF test found several items that must be corrected. }\end{array}$ \\
\hline
\end{tabular}

Corresponding Author:
Yuyun Elizabeth Patras,
Universitas Pakuan
Email: yuyunpatras64@gmail.com

\section{Pendahuluan}

Pendidikan merupakan jasa (service) yang diberikan lembaga pendidikan kepada masyarakat/konsumen (Rajab et al., 2011). Jasa pendidikan, termasuk jasa pendidikan tinggi yang diberikan universitas swasta maupun negeri, seiring dengan permintaan dari masyarakat saat ini sedang tumbuh (Abdullah \& Mohamad, 2016). Pertumbuhan permintaan jasa ini harus diiringi dengan pemberian jasa pendidikan yang bermutu, bukan hanya sarana fisik namun yang utama adalah dari para pengajar/dosennya (Dursun, Oskayba, \& Gökmen, 2013). Keadaan tersebut menyebabkan lembaga harus memberi perhatian penuh pada sejauhmana kualitas layanan (service quality) yang diberikan kepada pelanggannya/masyarakat (Esmaeilpour \& Ranjbar, 2016).

Pada sebuah universitas, agenda pemberian kualitas layanan pada pelanggannya menjadi sangat penting (Rajab et al., 2011). Kenapa penting, karena mahasiswa sebelum mendaptar pada sebuah universitas akan menjadikan kualifikasi pelayanan universitas tersebut sebagai pertimbangan utama (Dursun et al., 2013). Oleh karena itu mengimplementasikan pelayanan terbaik bagi mahasiswa merupakan solusi bertahan bagi universitas swasta maupun negeri (Stefan, 2010). Apalagi sejalan dengan perubahan terjadi di masyarakat, hubungan antara penyedia jasa dan pelangganya semakin dinamis, sehingga lembaga penyedia jasa untuk terus menerus mengevaluasi jasa yang diberikannya (Kumar, Shekhar, Lassar, \& Chen, 2018). Sebuah lembaga yang tidak memberikan kualitas layanan terbaik pada pelanggannya tidak akan mampu berkompetisi (Roy, 2019).

Berdasarkan pemikiran bahwa pemberian jasa, termasuk jasa dalam bidang akademik, antara lain pengajaran yang dilakukan dosen di sebauha universitas, maka jasa tersebut diperlukan evaluasi. Evaluasi 
yang dimaksud adalah mempertanyakan sejauh mana jasa yang diberikan dosen sudah memenuhi harapan (expected) mahasiswa. Penelitian ini akan berfokus pada tema tersebut. Hal baru dalam penelitian ini yaitu metode menggunakan metode bauran (mixed method) dan analisisnya menggunakan pemodelan Rasch, sedangkan instrument dikembangkan dari 5 dimensi kualitas layanan, yaitu: tangibility, reliability, responsiveness, assurance, dan empathy(Roy, 2019) yang kemudian dikembangkan ke dalam 32 butir pernyataan.

Kualitas layanan (service quality) didefinisikan sebagai pemberian layanan nyata yang dilakukan sebuah organisasi untuk memenuhi harapan dan persepsi pelangganya (Boon, Shukur, \& Bassim, 2016). Kualitas layanan berarti organisasi mengerti dan memahami persepsi dan harapan pelanggan sehingga organisasi menjadikan hal itu sangat penting untuk memperkirakan pemberian kualitas layanan (Deb \& Ahmed, 2018). Pemberian kualitas layanan terbukti dapat memuaskan pelanggan dan memengaruhi perilaku pelanggan (Oriade \& Scho, 2019), kualitas layanan juga berkorelasi sangat signifikan pada kehendak untuk menggunakan jasa atau oroduk secara berulang oleh para pelangganya (Prentice \& Kadan, 2019).

Banyak ragam pengukuran kualitas layanan. Namun demikian terdapat 5 dimensi kualitas layanan yang sering digunakan, yaitu: tangibles, empathy, assurance, reliability dan responsiveness(Boon et al., 2016). Hal itu diperkuat peneliti lainnya bahwa kualitas layanan memiliki dimensi sebagai berikut: physical dimensions or tangibility, reliability, responsiveness, and assurance, and empathy(Esmaeilpour \& Ranjbar, 2016). Lebih jauh peneliti lainnya menjabarkan setiap dimensi yaitu: (1) Tangibles meliputi fasilitas fisik, peralatan, dan penampakan dari sisi personal dan cara berkomunikasi; (2) Reliability meliputi kinerja pelayanan berdasarkan prinsip akurasi dan kejujuran; (3) Responsiveness meliputi kesiapan dan kesanggupan memberikan layanan terbaik bagi pelanggan; (4) Assurance meliputi kompetensi, kebaikan, integritas dan rasa aman yang ditunjukan pemberi layanan; (5) Empathy meliputi akses, komunikasi dan pemahaman si pemberi layanan kepada yang dilayani (Dursun et al., 2013).

Pada lembaga layanan pendidikan seperti universitas, persepsi mahasiswa sebagai pelanggan didasarkan pada kualitas dan layanan pendidikan yang ditawarkan. Di lembaga pendidikan tinggi, kualitas layanan yang dirasakan yang meliputi belajar mengajar atau perkulihan, fasilitas dan layanan pendukung lainnya (Azam, 2018). Jika kualitas layanan pendidikan diterima baik oleh mahasiswa, maka akan menimbulkan kepuasan pada pelanggan (Rajab et al., 2011). Berdasarkan paparan di atas untuk selanjutnya peneliti akan menyebut upaya pemberian layanan pada mahasiswa sebagai kualitas layanan dosen (lecturer's service quality), khsusnya di universitas swasta.

Pemodelan Rasch (Rasch Model) merupakan sebuah pendekatan statistik untuk mengukur kinerja, sikap, dan persepsi manusia. Penamaan tersebut berdasarkan nama penemunya, Georg Rasch, berkebangsaan Denmark, ia menerbitkan teorinya pada tahun 1960 dan meninggal pada tahun 1980(Tesio, 2003). Analisis data menggunakkan pemodelan Rasch dapat diterapkan pada ilmu social (Bond \& Fox, 2007), penggunaan pemodelan Rasch sangat direkomendasikan untuk meningkatkan kualitas pengukuran, baik dalam penelitian qualitative maupun quantitative (Stef van Buuren, 2015).

Pemodelan Rasch mengacu pada teori response butir atau aitem (item response theory) yang memberikan alternatif yang lebih baik untuk memeriksa kualitas penilaian skala psikometrik dan menginformasikannya dengan lebih baik (Zile-Tamsen, 2017). Pemodelan Rasch dapat digunakan dalam berbagai penelitian. Pemodelan Rasch digunakan untuk meneliti bidang perilaku (Bond \& Fox, 2007) kesehatan mental (Tesio, 2003) dan kinerja karyawan (Jiao, Lissitz, \& Macready, 2011). Dalam pendidikan, misalnyauntuk membuat instrumen yang dapat mengukur kondusifitas dalam pembelajaran (Nguyen Thanh Dong, 2014).

Pemodelan Rasch dalam menganalisis data memiliki berbagai keunggunlan, misalnya ia dapat menjelaskan aitem (butir) pernyataan dan orang (person) (Carvalho, Primi, \& Meyer, 2012). Dalam pemodelan Rasch, unit pengukuran skala untuk kemampuan dan kesulitan aitem (butir) dikenal sebagai "logit", kontraksi "unit odds log". Adanya unit pengukuran tersebut membuat Model Rasch dapat membantu untuk mengatasi pengukuran aitem (butir) dengan cara yang benar(Wu \& Adams, 2007).Pemodelan Rasch mampu mengatasi masalah integritas data melalui akomodasi transformasi logit dengan menerapkan logaritma pada rasio ganjil dari data mentah yang diperoleh dari responden(Linacre, 2010).

\section{Metode}

Penelitian ini bertujuan untuk membuat instrument penelitian, yaitu kualitas layanan dosen. Penelitian ini menggunakan metode kombinasi (mixed-methode) (Sugiyono, 2015) yang dimulai secara kualitaitif dan 
dilanjutkan dengan kuantitatif deskriptif (Zohrabi, 2013). Proses kualitatif dimulai dengan kegiatan kajian literature, wawancara mahasiswa, dan validasi ahli. Sdangkan proses kuantitatif (Klette, 2012), yaitu melakukan analisis data menggunakan pemodelan Rasch (Rasch model). Kajian literatur dilakukan untuk mendapatkan validitas logis (logical validity) (John 1. Pollock, 1967), yaitu intrumen yang ditemukan berdasarkan pada teori kualitas layanan (Meerah, Osman, Zakaria, \& Ikhsan, 2012). Wawancara pada mahasiswa bertujuan untuk mendapatkan butir-butir penyataan yang sesuai dengan konteks penelitian. Validasi ahli bertujuan untuk mendapatkan validitas isi (content validaty) (Ghazali, 2016). Pengumpulan data melalui instrumen kuisioner yang disebarkan melalui Google Form. Jumlah responden sebanyak 543 mahasiswa. Penelitian ini dilakukan di Universitas Pakuan, Jawa Barat, yang telah dikenal sebagai salah satu universitas swasta terbesar di Bogor, Jawa Barat, Indonesia. Adapun gambaran demografi responden terlihat pada table 1 .

Tabel 1. Demografi Responden Penelitian

\begin{tabular}{lllll}
\hline \multicolumn{1}{c}{ Jenis Kelamin } & $\begin{array}{c}\text { Status Sekolah } \\
\text { Menengah }\end{array}$ & Tahun Masuk & Pekerjaan Orang Tua & Fakultas \\
\hline Laki-laki, $\mathrm{n}=139$ & Negeri, $\mathrm{n}=301$ & $2018, \mathrm{n}=188$ & Wiraswasta, $\mathrm{n}=167$ & Ekonomi, $\mathrm{n}=213$ \\
\hline $\begin{array}{l}\text { Perempuan, } \\
\mathrm{n}=404\end{array}$ & Swasta, $\mathrm{n}=242$ & $2017, \mathrm{n}=108$ & PNS, $\mathrm{n}=131$ & Pendidikan, $\mathrm{n}=164$ \\
\hline & $2016, \mathrm{n}=92$ & Swasta, $\mathrm{n}=122$, & Hukum, $\mathrm{n}=56$ \\
\hline & $2015, \mathrm{n}=123$ & TNI/Polri, $\mathrm{n}=21$ & MIPA, $\mathrm{n}=51$ \\
\hline & & Lainnya, $\mathrm{n}=102$ & $\begin{array}{l}\text { Sosial Budaya, } \mathrm{n}= \\
36\end{array}$ \\
\hline & & & Teknik, $\mathrm{n}=23$ \\
\hline
\end{tabular}

Kontruksi instrumen menggunakan validitas logis, yaitu sebuah instrumen yang memenuhi persyaratan valid berdasarkan hasil penalaran karena dirancang secara baik, mengikuti teori dan ketentuan yang ada (John 1. Pollock, 1967). Berdasarkan kontruksi tersebut peneliti mendapatkan 5 dimensi kualitas layanan, yaitu: (1) tangible, (2) reliability (3) responsiveness (4) assurance, (5) empathy. Langkah berikutnya adalah melakukan wawancara terhadap mahasiswa untuk mendapatkan butir-butir pernyataan sesuai dengan dimensi kualitas layanan. Berdasarkan wawancara pada mahasiswa diperoleh 4 butir yang terkait dengan dimensi tangible (TGL), 6 butir yang terkait reliability (RLB), 6 butir yang terkait responsiveness (RSP), 11 butir yang terkait dengan assurance (ASR), 5 butir yang terkait empathy (EMP). Jadi keseluruhan intrumen ini memiliki 32 butir penyataan. Draf instrument selanjutnya dinilai oleh dua ahli. Rekomendasi keduanya berupa saran perbaikan, khususnya konten (Ghazali, 2016). Saran tersebut ditindaklanjuti oleh peneliti.

Butir instrument yang terkait tangible yaitu: (TGL1) Dosen berpenampilan rapi ketika mengajar; (TGL2) Dosen menyampaikan materi kuliah berdasarkan referensi yang relevan; (TGL3) Dosen terlihat percaya diri; (TGL4) Dosen menggunakan media pembelajaran yang memudahkan mahasiswa untuk memahami materi kuliah.

Butir instrument yang terkait reliability, yaitu: (RLB1) Dosen menggunakan buku ajar yang relevan dengan mata kuliah; (RLB2) Dosen menginformasikan sumber-sumber belajar (link buku, jurnal, materi pelajaran) kepada mahasiswa; (RLB3) Dosen mengajar sesuai dengan jadwal yang diatur oleh fakultas/program studi; (RLB4) Dosen mengisi daftar hadir mahasiswa dan dosen; (RLB5) Dosen memberikan nilai kepada mahasiswa sesuai ketentuan yang ditetapkan.

Butir instrument yang terkait responsiveness, yaitu: (RSP1) Dosen mengembalikan hasil ujian kepada mahasiswa; (RSP2) Dosen memberikan pengayaan kepada mahasiswa yang membutuhkan; (RSP3) Dosen menggunakan teknologi pembelajaran terbaru dalam perkuliahan; (RSP4) Dosen memeriksa tugas perkuliahan yang diberikan kepada mahasiswa; (RSP5) Dosen menyampaikan rencana pembelajaran kepada mahasiswa; (RSP6) Dosen memberikan petunjuk yang jelas ketika memberikan tugas kepada mahasiswa.

Butir instrument yang terkait assurance, yaitu: (ASR1) Dosen membahas presentasi mahasiswa; (ASR2) Dosen memberikan sanksi terhadap mahasiswa yang melanggar peraturan perkuliahan; (ASR3) Dosen mampu menyelesaikan masalah yang terjadi dalam perkulihan dengan efektif; (ASR4) Dosen mampu merespon pertanyaan mahasiswa dengan jawaban yang disertai data; (ASR5) Dosen melakukan teguran 
kepada mahasiswa sesuai aturan yang berlaku; (ASR6) Dosen memberikan bimbingan sesuai peraturan di kampus; (ASR7) Dosen memberikan rasa aman kepada mahasiswa; (ASR8) Dosen mampu membangun rasa percaya dari mahasiswa; (ASR9) Dosen menghindari melakukan kritik pada mahasiswa di depan teman-temannya; (ASR10) Dosen menyampaikan materi kuliah dengan bahasa yang mudah dipahami; (ASR11) Dosen memberikan perhatian kepada kemajuan belajar mahasiswa.

Butir instrument yang terkait empathy yaitu:(EMP1) Dosen berinteraksi kepada mahasiswa secara adil; (EMP2) Dosen melakukan perwalian sesuai ketentuan fakultas/program studi; (EMP3) Dosen dapat bekerjasama dengan mahasiswa; (EMP4) Dosen meluangkan waktu yang cukup untuk melayani kebutuhan akademik mahasiswa; (EMP5) Dosen meminta unpan balik (feed-back) dari mahasiswa tentang perkulihan yang diampunya.

Pengukuran jawaban responden menggunakan skala Likert (Brinkman, 2009) dengan lima pilihan peringkat (rating), semakin besar skor jawaban responden berarti hal itu menunjukan responden lebih menyetujui butir pernyataan dan sebaliknya. Ratingnya mulai $1=$ sangat tidak setuju, 2 = tidak setuju, $3=$ netral, 4 = setuju, 5 = sangat setuju (Hendriks et al., 2012). Pengujian instrument dan persepsi atas kualitas layanan menggunakan pemodelan Rasch. Proses pengolahan data dimulai dengan input data dari kuesioner yang berbentuk skala ordinal kemudian dikonversi ke skala interval menggunakan pemodelan Rasch melalui perangkat lunak Winsteps versi 3.73 .

Pengujian dilakukan pada 4 hal, yaitu: (1) Pengujian validitas butir (item) instrument dengan menggunakan Item (Column): Fit Order, dimana Nilai Outfit Mean Square (MNSQ) yang diterima $.05<\mathrm{MNSQ}<1.5$, Nilai Outfit Z-Standard(ZSTD) yang diterima $-2<$ ZSTD $<+2$, Nilai Point Measure Correlation(Pt Mean Corr): $0.4<$ PtMean Cor $<0.85$ dan terakhir menggunakan rating (partial-credit) scale, dengan kriteria bahwa jika semua rating (angka) memiliki titik puncak, maka instrument tersebut memiliki validitas (Bambang Sumintono, 2015); (2) Pengujian reliabilitas instrument menggunakan summary statistic; (3) Pengujian butir instrumen yang sulit dan mudah disetujui responden menggunakan item measure dan item: dimensinality; dan (4) Pengujian persepsi atau bias berdasarkan demografi responden menggunakan Differential Item Functional (DIF) plot (Bambang Sumintono, 2014). Kriteria adanya perbedaan persepsi yang siginifikan menggunakan tabel 30.4 pada Winsteps software dengan kriteria bahwa perbedaan persepsi dikatakan signifikan jika nilai probabilitas menunjukan lebih kecil dari $0.05(\mathrm{p}<0.05)$ (Bambang Sumintono, 2015).

\section{Hasil dan Pembahasan}

Pengujian validitas butir instrument menggunakan Item (Column): Fit Order pada Winsteps seperti terdapat pada Table 2 dengan kriteria pengambilan keputusan bahwa butir pernyataan dinyatakan valid apabila OUTFIT MNSQ berada pada rentang $0.5<$ MNSQ $<1.5$. Memperhatikan hal itu maka butir yang "tidak valid" pada instrument kualitas layanan dosen ini berdasarkan OUTFIT MNSQ ini adalah butir 10, yaitu RSP1 dimana nilai MNSQ menunjukan 1.85 yang berarti lebih besar dari 1.5. Sisanya sebanyak 31 butir memenuhi kriteria OUTFIT MNSQ yang dimaknai bahwa 31 butir (item) sudah fit atau tepat mengukur.

Pengujian validitas butir instrument menggunakan Item (Column): Fit Order pada Winsteps dengan melihat nilai OUTFIT Z-STANDARD (ZSTD) dengan kriteria valid jika $-2<$ ZSTD $<+2$, maka ditemukan bahwa terdapat 8 butir yang memenuhi kriteria validitas, yaitu butir: RSP4 (1.8), RSP3 (1.3), TGL4 (0.7), EMP2 (0.2), (RSP5 (1.3), TGL2 (-0.5), RLB2 (-0.9) dan RSP5 (-1.3). Ini berarti sisanya sebanyak 24 tidak memenuhi OUTFIT Z-STANDARD atau harus diperbaiki.

Pengujian validatas intrumen dengan melihat nilai Point Measure Correlation (Pt Mean Corr) dengan kriteria valid jika $0.4<$ PtMean Cor $<0.85$, maka ditemukan bahwa polarity item (item polaritas) memiliki nilai Point Measure Correlation yang positif dan memenuhi kriteria yang dipersyaratkan. Ini berarti semua butir instrument kualitas layanan dosen tidak ada konflik antara butir dan konstruk yang diukur. Dengan demikian dari 3 kriteria validitas (OUTFIT MNSQ, OUTFIT Z-STANDARD, dan Point Measure Correlation) hanya terdapat 1 butir (RSP1) yang tidak memenuhi 2 syarat lainya sehingga harus didrop atau tidak digunakan. 
Tabel 2. Hasil Uji Item (Column): Fit Order

\begin{tabular}{|c|c|c|c|c|c|c|c|c|c|c|c|c|}
\hline $\begin{array}{l}\text { | ENTRY } \\
\text { | NUMBER }\end{array}$ & SCORE & COUNT & MEASURE & S.E. |MNSQ & ZSTD|I & INSQ & $\mathrm{ZSTD} \mid \mathrm{CO}$ & $\mathrm{RR}$. & EXP.। & OBS $\%$ & $\mathrm{EXP} \div$ & Item \\
\hline & & & & & 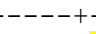 & & ----+ & 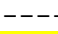 & ----+ & ---- & -----+ & ----- \\
\hline 1 & 2327 & 543 & -1.31 & $.07 \mid 1.52$ & 6.617 & .41 & $3.7 \mid \mathrm{B}$ & .62 & $.67 \mid$ & 52.4 & 61.91 & TGL1 \\
\hline 24 & 1859 & 543 & .73 & $.06 \mid 1.47$ & 6.711 & .47 & $6.5 \mid \mathrm{C}$ & .69 & $.77 \mid$ & 52.6 & 51.21 & ASR 9 \\
\hline 31 & 1913 & 543 & .52 & $.06 \mid 1.38$ & $5.6 \mid 1$ & .37 & $5.1 \mid \mathrm{D}$ & .72 & .761 & 59.3 & 52.31 & EMP 5 \\
\hline 5 & 2037 & 543 & .03 & $.06 \mid 1.05$ & .911 & .28 & $3.8 \mid \mathrm{G}$ & .72 & .741 & 57.3 & 54.21 & RLB1 \\
\hline 16 & 2018 & 543 & .11 & $.06 \mid 1.21$ & $3.21=$ & .27 & $3.7 \mid \mathrm{H}$ & .71 & .741 & 56.5 & 53.81 & ASR1 \\
\hline 11 & 1760 & 543 & 1.10 & $.06 \mid 1.26$ & 4.017 & .26 & $3.8 \mid I$ & .73 & .781 & 48.3 & 49.91 & RSP2 \\
\hline 3 & 2259 & 543 & -.96 & $.07 \mid 1.19$ & $2.7 \mid$ & .26 & $2.8 \mid \mathrm{J}$ & .66 & .691 & 56.3 & 58.71 & TGL3 \\
\hline 7 & 2010 & 543 & .14 & $.06 \mid 1.07$ & $1.2 \mid 1$ & .18 & $2.5 \mid \mathrm{K}$ & .71 & .741 & 54.8 & 53.81 & RLB3 \\
\hline 13 & 1997 & 543 & .19 & $.06 \mid 1.00$ & $.1 \mid 1$ & .13 & $1.8 \mid \mathrm{L}$ & .74 & .751 & 56.1 & 53.81 & RSP 4 \\
\hline 6 & 2100 & 543 & -.23 & .071 .96 & -.61 & .93 & -.910 & .73 & .731 & 59.6 & 55.31 & RLB2 \\
\hline 14 & 2080 & 543 & -.15 & .061 .95 & -.71 & .91 & $-1 \cdot 3 \mid n$ & .75 & .731 & 58.3 & 55.01 & RSP 5 \\
\hline 20 & 2106 & 543 & -.26 & $.07 \mid .92$ & $-1 \cdot 2 \mid$ & .85 & $-2.1 \mid \mathrm{m}$ & .75 & .731 & 64.9 & 55.31 & ASR 5 \\
\hline 9 & 2122 & 543 & -.33 & $.07 \mid .85$ & $-2.5 \mid$ & .84 & $-2.2 \mid 1$ & .75 & .721 & 64.7 & $55.7 \mid$ & RLB5 \\
\hline 27 & 2028 & 543 & .07 & $.061 . .83$ & $-2.9 \mid$ & .79 & $-3.3 \mid \mathrm{k}$ & .78 & .741 & 64.7 & 54.11 & EMP1 \\
\hline 22 & 2051 & 543 & -.03 & .061 .80 & -3.41 & .74 & $-4.1 \mid j$ & .78 & .741 & 64.7 & 54.51 & ASR 7 \\
\hline 15 & 2017 & 543 & .11 & .061 .76 & $-4.2 \mid$ & .74 & $-4.1 \mid i$ & .78 & .741 & 64.9 & 53.81 & RSP 6 \\
\hline 25 & 2087 & 543 & -.18 & $.07 \mid .72$ & $-4.8 \mid$ & .75 & $-3.8 \mid h$ & .78 & .731 & 66.7 & 55.21 & ASR10 \\
\hline 30 & 1972 & 543 & .29 & .061 .75 & $-4.4 \mid$ & .74 & $-4.4 \mid g$ & .79 & .751 & 64.7 & 53.41 & EMP 4 \\
\hline 26 & 2011 & 543 & .14 & $.06 \mid .72$ & $-4.8 \mid$ & .74 & $-4.2 \mid \mathrm{f}$ & .79 & .741 & 65.5 & 53.81 & ASR11 \\
\hline 23 & 2047 & 543 & -.01 & .061 .73 & $-4.8 \mid$ & .70 & $-4.9 \mid e$ & .79 & .741 & 65.9 & $54.5 \mid$ & ASR 8 \\
\hline
\end{tabular}

Pengujian validitas konstrak dengan menggunakan item: dimensionality pada Winstep, dengan kriteria bahwa dinyatakan memiliki kemampuan mengukur range variable atau mengukur semua responden jika Raw Variance Explained by measures berada di atas 40\% untuk data type Likerts (Bambang Sumintono, 2015), maka seperti pada Tabel 3 ditemukan bahwa nilai yang dimiliki oleh Raw Variance Explained by measures sebesar 61,6\%. Berdasarkan hal itu maka instrument kualitas layanan dosen ini memiliki validitas konstruk atau mampu mengukur range variable atau mengukur semua responden. Namun demikian jika dilihat menggunakan Wright Map, terlihat jelas seperti pada Tabel 7 terdapat pengumpulan butir (item) yang terkumpul di tengah. Ini berarti terdapat butir-butir instrument yang harus diperbaiki.

Tabel 3. Hasil Pengujian Item: Dimensionality

\begin{tabular}{|c|c|c|c|c|c|}
\hline Total raw variance in observations & $=$ & $\begin{array}{r}-- \text { Emr } \\
80.8\end{array}$ & $\begin{array}{l}\text { oirical } \\
100.0 \%\end{array}$ & -- & $\begin{array}{l}\text { odeled } \\
100.0 \%\end{array}$ \\
\hline Raw variance explained by measures & $=$ & 49.8 & $61.6 \%$ & & $61.6 \%$ \\
\hline Raw variance explained by persons & $=$ & 31.7 & $39.2 \%$ & & $39.2 \%$ \\
\hline Raw Variance explained by items & $=$ & 18.1 & $22.4 \%$ & & $22.4 \%$ \\
\hline Raw unexplained variance (total) & $=$ & 31.0 & $38.4 \%$ & $100.0 \%$ & $38.4 \%$ \\
\hline Unexplned variance in 1 st contrast & $=$ & 3.1 & $3.8 \%$ & $10.0 \%$ & \\
\hline Unexplned variance in 2 nd contrast & $=$ & 2.8 & $3.5 \%$ & $9.1 \%$ & \\
\hline Unexplned variance in $3 r d$ contrast & $=$ & 2.0 & $2.5 \%$ & $6.5 \%$ & \\
\hline Unexplned variance in 4 th contrast & $=$ & 1.6 & $2.0 \%$ & $5.2 \%$ & \\
\hline Unexplned variance in 5th contrast & $=$ & 1.4 & $1.8 \%$ & $4.6 \%$ & \\
\hline
\end{tabular}


Hasil pengujian validitas dengan melihat hasil test rating (partial -credit) scale sebagaimana terdapat pada Tabel 4 ditemukan bahwa setiap rating $(1,2.3$. 4. 5) mempunyai puncak yang terpisah; atau berarti probabilitas tiap rating terlihat jelas perbedaanya oleh responden. Berdasarkan Tabel 3 bahwa instrument kualitas layanan dosen mampu dibedakan ratingnya oleh responden.

Tabel 4. Hasil Uji rating (partial-credit) scale

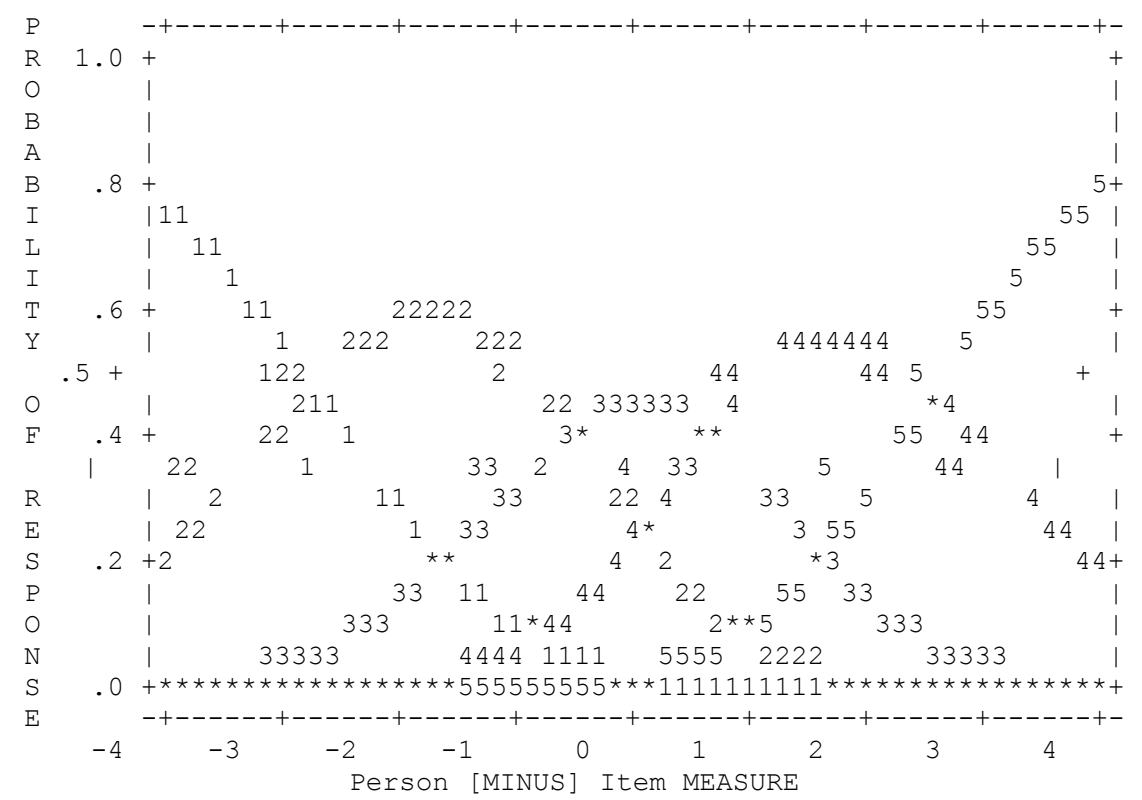

Hasil pengujian menggunakan summary statistic untuk instrument kualitas layanan dosen sebagaimana terlihat pada Tabel 5 bahwa instrument kualitas layanan ini memiliki reliabilitas orang (person), alpha cronbach dan reliabilitas butit (item) mendekati 1. Artinya reliabilitas instrument ini baik karena instrument ini memiliki reliabilitas person 0.97, reliabilitas alpha cronbach 0.94 dan reliabilitas butir (item) 0.98 . Ini berarti instrument kualitas layanan ini jika digunakan oleh peneliti lain maka hasilnya relatif ajeg atau akan memiliki kemiripin hasil.

Tabel 5. Hasil Uji Menggunakan Summary Statistic

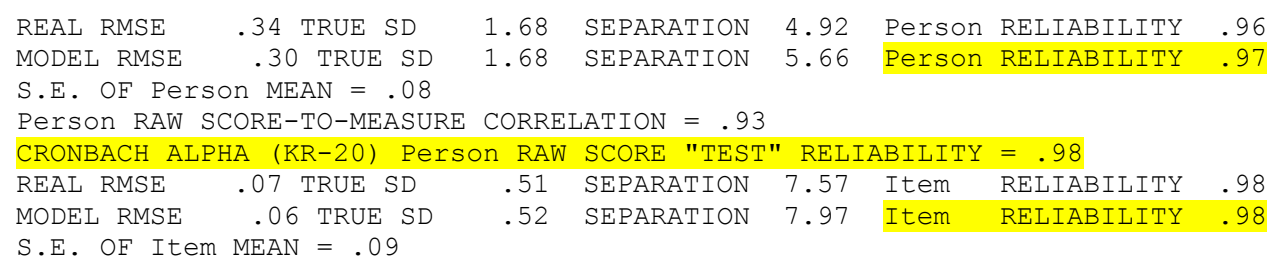

Hasil pengujian menggunakan item measure dan variable map untuk mengetahui butir (item) yang paling sulit disetujui dan paling mudah disetujui oleh responden ditemukan sebagaimana dalam Tabel 6 dan Tabel 7, dimana terdapat 10 butir (item) yang sulit disetujui reponden, yaitu: RSP1, RSP2, ASR9, EMP5, RSP3, ASR1, EMP4, RLB3, RSP4, dan TGL4. Sedangkan yang paling mudah disetujui yaitu TGL1. Namun demikian jika memperhatikan Tabel 7 ditemukan butir (item) instrument terlalu menumpuk di tengah atau kurang menyebar sesuai dengan dengan responden (mahasiswa). Jika melihat Standar Deviasi (S.D) pada Tabel 6 terdapat S.D sebesar 0.52, maka ini berarti range tingkat kesulitan butir (item) tidak beragam sehingga perlu diperbaiki. 
Table 6. Hasi Uji Items Measure

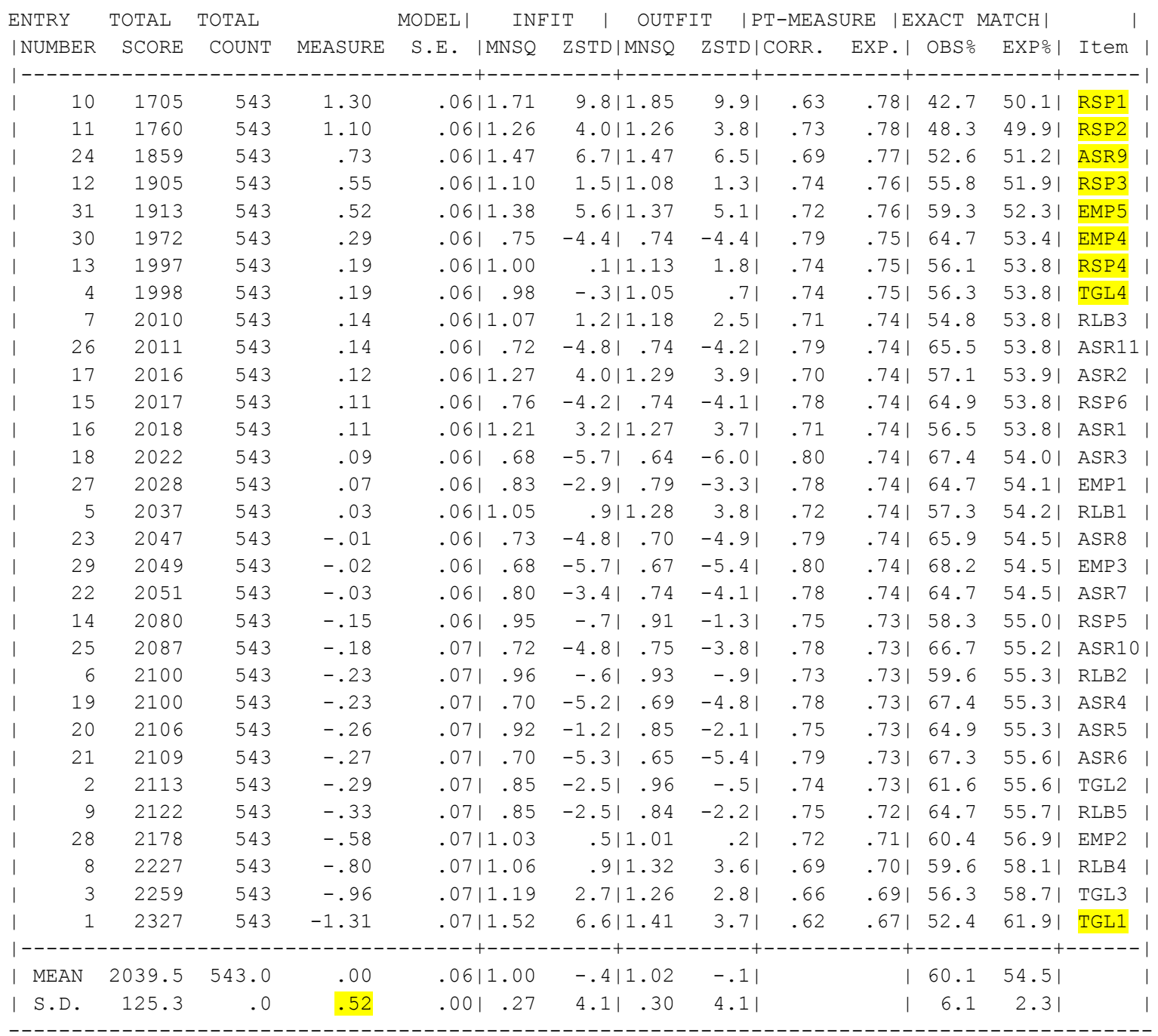

Keterangan Tabel $4 . \mathrm{TGL}=$ tangible, $\mathrm{RLB}=$ reliability, $\mathrm{RSP}=$ responsiveness, $\mathrm{ASR}=$ assurance, $\mathrm{EMP}=$ empathy. 
Tabel 7. Hasil Uji Variable Map

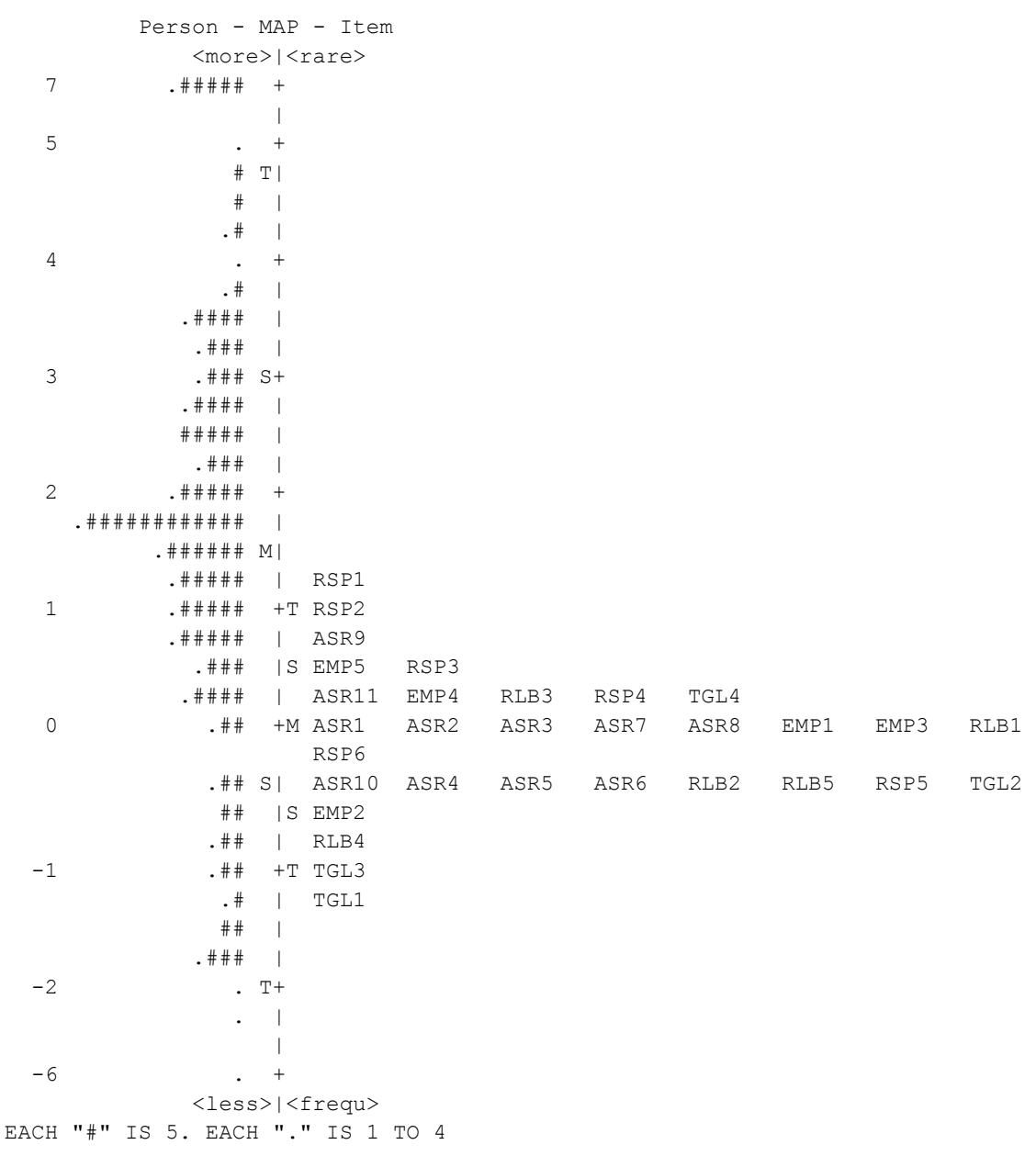

Hasil tes menggunakan Differential Item Functional (DIF) plot dan nilai probabilitas tabel 30.4 pada Winstep, dimana perbedaan persepsi dinyatakan signifikan jika nilai $\mathrm{p}<0.05$, maka seperti Gambar 1 dan Tabel 7 bahwa mahasiswa perempuan (garis 2 merah) dan mahasiswa laki-laki (garis 1 biru ) memiliki perbedaan persepsi yang signifikan pada 8 butir instrument, yaitu: TGL1 ( $p=0.0176)$, RLB4 $(p=0.0216)$, RLB5 ( $p=0.0005)$, RSP1 ( $p=0.0176)$ RSP2 (0.0036), RSP3 ( $p=0.0065)$, ASR2 ( $p=0.0322)$, dan ASR7 $(p=0.00185)$. Ini berarti kedelapan butir yang dipersepsikan berbeda itu harus diperbaiki karena masih memiliki bias gender secara nyata.

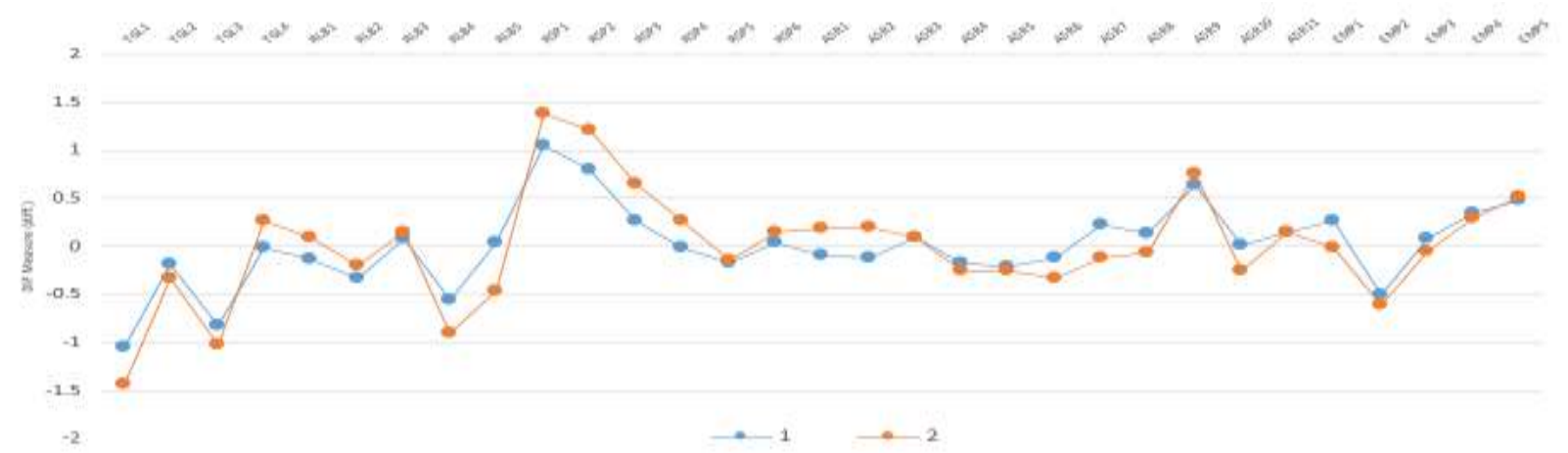

Gambar 1 Hasil Differential Item Functional (DIF) plot Berdasarkan Jenis Kelamin

Keterangan: Mahasiswa laki-laki (biru) , 2 = Mahasiswa perempuan (merah) 
Tabel 7. Hasil Uji D.F Person Classes Berdasarkan Jenis Kelamin

\begin{tabular}{|c|c|c|c|c|c|c|c|c|c|}
\hline \multicolumn{2}{|c|}{$\begin{array}{l}\text { Person } \\
\text { CLASSES }\end{array}$} & $\begin{array}{l}\text { SUMMARY DIF } \\
\text { CHI-SQUARE }\end{array}$ & D.F. & PROB. & \multicolumn{2}{|c|}{ BETWEEN-CLASS } & \multicolumn{3}{|c|}{ Item } \\
\hline & & --------- & & ------ & ------------ & ------- & & ----- & \\
\hline & 2 & 5.6328 & 1 & .0176 & 2.3990 & 1.1898 & 1 & TGL1 & | \\
\hline & 2 & .8598 & 1 & .3538 & .3565 & -.1457 & 2 & TGL2 & | \\
\hline & 2 & 1.6018 & 1 & .2056 & .6786 & .2142 & 3 & TGL3 & । \\
\hline & 2 & 3.3403 & 1 & .0676 & 1.3072 & .6695 & 4 & TGL4 & । \\
\hline & 2 & 2.2178 & 1 & .1364 & .8657 & .3718 & 5 & RLB1 & | \\
\hline & 2 & .8357 & 1 & .3606 & .3226 & -.1951 & 6 & RLB2 & । \\
\hline & 2 & .2092 & 1 & .6474 & .1022 & -.6582 & 7 & RLB3 & । \\
\hline | & 2 & 5.2779 & 1 & .0216 & 2.2069 & 1.1119 & 8 & RLB4 & I \\
\hline & 2 & 11.9709 & 1 & .0005 & 4.9607 & 1.9680 & 9 & RLB5 & I \\
\hline & 2 & 5.6445 & 1 & .0175 & 2.1791 & 1.1003 & 10 & RSP1 & । \\
\hline & 2 & 8.4891 & 1 & .0036 & 3.3107 & 1.5117 & 11 & RSP2 & । \\
\hline | & 2 & 7.4019 & 1 & .0065 & 2.9111 & 1.3790 & 12 & RSP3 & | \\
\hline | & 2 & 3.4783 & 1 & .0622 & 1.3618 & .7014 & 13 & RSP 4 & | \\
\hline | & 2 & .0519 & 1 & .8197 & .0222 & -1.0535 & 14 & RSP 5 & I \\
\hline | & 2 & .4653 & 1 & .4952 & .1770 & -.4588 & 15 & RSP 6 & I \\
\hline & 2 & 3.7063 & 1 & .0542 & 1.4550 & .7539 & 16 & ASR1 & I \\
\hline | & 2 & 4.5859 & 1 & .0322 & 1.8057 & .9333 & 17 & ASR2 & I \\
\hline | & 2 & .0000 & 1 & 1.0000 & .0040 & -1.3142 & 18 & ASR3 & I \\
\hline | & 2 & .3019 & 1 & .5827 & .1276 & -.5819 & 19 & ASR 4 & I \\
\hline | & 2 & .0796 & 1 & .7779 & .0543 & -.8468 & 20 & ASR5 & I \\
\hline | & 2 & 2.2371 & 1 & .1347 & .9173 & .4112 & 21 & ASR 6 & I \\
\hline | & 2 & 5.5476 & 1 & .0185 & 2.2503 & 1.1299 & 22 & ASR7 & I \\
\hline | & 2 & 1.8039 & 1 & .1792 & .7319 & .2618 & 23 & ASR8 & | \\
\hline | & 2 & .8408 & 1 & .3592 & .3220 & -.1959 & 24 & ASR9 & I \\
\hline | & 2 & 3.1407 & 1 & .0764 & 1.2806 & .6537 & 25 & ASR10 & I \\
\hline | & 2 & .0000 & 1 & 1.0000 & .0009 & -1.4419 & 26 & ASR11 & I \\
\hline | & 2 & 3.5649 & 1 & .0590 & 1.4383 & .7446 & 27 & EMP1 & I \\
\hline | & 2 & .4185 & 1 & .5177 & .1789 & -.4545 & 28 & EMP2 & I \\
\hline | & 2 & .9813 & 1 & .3219 & .4005 & -.0863 & 29 & EMP 3 & I \\
\hline | & 2 & .1433 & 1 & .7050 & .0849 & -.7176 & 30 & EMP 4 & I \\
\hline | & 2 & .1765 & 1 & .6744 & .0873 & -.7090 & 31 & EMP 5 & 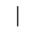 \\
\hline
\end{tabular}

Hasil tes menggunakan Differential Item Functional (DIF) plot dan nilai probabilitas tabel 30.4, dimana perbedaan persepsi dinyatakan signifikan jika nilai $\mathrm{p}<0.05$ seperti pada Gambar 2 dan Tabel 8, maka berdasarkan kriteria tersebut bahwa tidak ada perbedaan persepsi (bias) yang signifikan antara mahasiswa yang berasal dari sekolah menengah negeri (garis 1 biru) dan mahasiswa yang berasal dari sekolah menengah swasta (garis 2 merah). Ini berarti instrument kualitas layanan dosen dapat mengukur dengan baik mahasiswa yang berasal dari Sekolah Mengah (SMU/K) yang berstatus negeri maupun swasta.

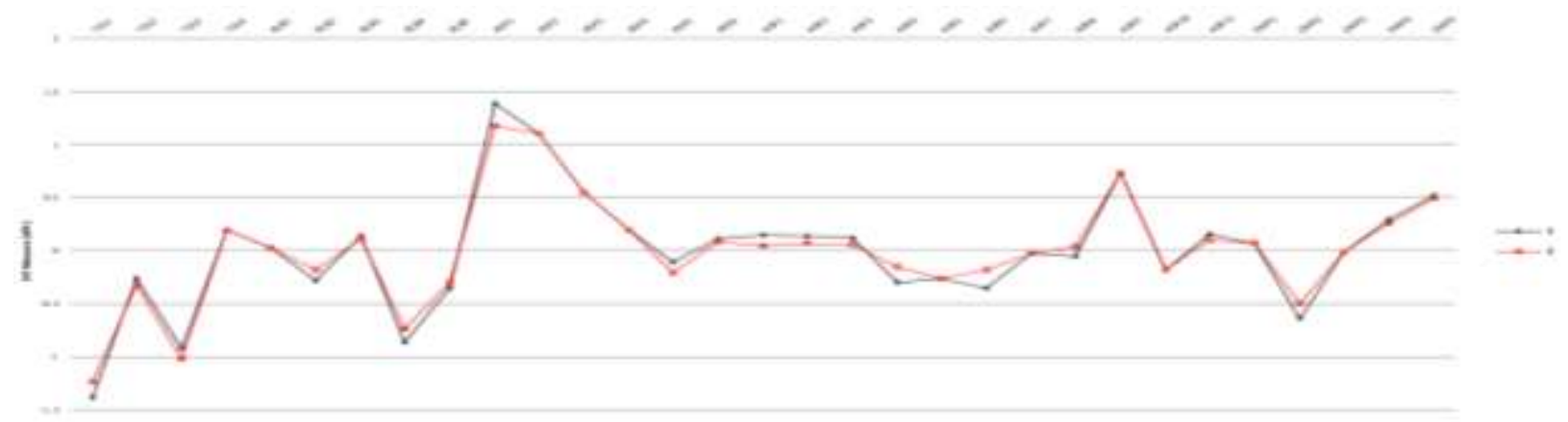

Gambar 2: Hasil Differential Item Functional (DIF) plot Berdasarkan Status Sekolah Menengah

Keterangan: Gambar 2: 1 = Sekolah Sekolah Negeri, 2 = Sekolah Menengah Swasta 
Tabel 8. Hasil Uji D.F Person Classes Berdasarkan Status Sekolah Menengah

\begin{tabular}{|c|c|c|c|c|c|c|c|c|}
\hline \multirow{2}{*}{\multicolumn{2}{|c|}{$\begin{array}{l}\text { | Person } \\
\text { CLASSES }\end{array}$}} & \multirow{2}{*}{$\begin{array}{l}\text { SUMMARY DIF } \\
\text { CHI-SQUARE }\end{array}$} & \multirow[b]{2}{*}{ D.F. } & \multirow[b]{2}{*}{ PROB . } & \multicolumn{2}{|c|}{ BETWEEN-CLASS } & \multicolumn{2}{|l|}{ Item } \\
\hline & & & & & MEAN-SQUARE & $t=Z S T D$ & Number & Name \\
\hline & - & -----1 & & --- & ----------- & ------- & ------- & ----- \\
\hline 1 & 2 & .8529 & 1 & .3557 & .4270 & -.0525 & 1 & TGL1 \\
\hline 1 & 2 & .3329 & 1 & .5640 & .1625 & -.4923 & 2 & TGL2 \\
\hline | & 2 & .4703 & 1 & .4929 & .2290 & -.3520 & 3 & TGL3 \\
\hline | & 2 & .0000 & 1 & 1.0000 & .0050 & -1.2877 & 4 & TGL4 \\
\hline | & 2 & .0000 & 1 & 1.0000 & .0003 & -1.5011 & 5 & RLB1 \\
\hline | & 2 & .5993 & 1 & .4388 & .2993 & -.2310 & 6 & RLB2 \\
\hline | & 2 & .0874 & 1 & .7675 & .0689 & -.7804 & 7 & RLB3 \\
\hline | & 2 & .7063 & 1 & .4007 & .3534 & -.1501 & 8 & RLB 4 \\
\hline | & 2 & .1215 & 1 & .7275 & .0614 & -.8131 & 9 & RLB5 \\
\hline | & 2 & 2.9999 & 1 & .0833 & 1.4903 & .7731 & 10 & RSP1 \\
\hline | & 2 & .0000 & 1 & 1.0000 & .0004 & -1.4956 & 11 & RSP2 \\
\hline | & 2 & .0000 & 1 & 1.0000 & .0189 & -1.0852 & 12 & RSP3 \\
\hline | & 2 & .0000 & 1 & 1.0000 & .0143 & -1.1348 & 13 & RSP 4 \\
\hline | & 2 & .6053 & 1 & .4366 & .2968 & -.2349 & 14 & RSP 5 \\
\hline | & 2 & .0825 & 1 & .7739 & .0646 & -.7990 & 15 & RSP 6 \\
\hline | & 2 & .6702 & 1 & .4130 & .3294 & -.1849 & 16 & ASR1 \\
\hline | & 2 & .3004 & 1 & .5836 & .1471 & -.5302 & 17 & ASR2 \\
\hline | & 2 & .2164 & 1 & .6418 & .1057 & -.6469 & 18 & ASR3 \\
\hline | & 2 & 1.3634 & 1 & .2429 & .6791 & .2147 & 19 & ASR 4 \\
\hline | & 2 & .0000 & 1 & 1.0000 & .0216 & -1.0588 & 20 & ASR5 \\
\hline | & 2 & 1.6916 & 1 & .1934 & .8425 & .3536 & 21 & ASR 6 \\
\hline | & 2 & .0000 & 1 & 1.0000 & .0415 & -.9153 & 22 & ASR7 \\
\hline | & 2 & .4932 & 1 & .4825 & .2461 & -.3205 & 23 & ASR8 \\
\hline | & 2 & .0000 & 1 & 1.0000 & .0003 & -1.5156 & 24 & ASR9 \\
\hline | & 2 & .0000 & 1 & 1.0000 & .0064 & -1.2565 & 25 & ASR10 \\
\hline | & 2 & .1998 & 1 & .6549 & .0976 & -.6731 & 26 & ASR11 \\
\hline | & 2 & .0000 & 1 & 1.0000 & .0076 & -1.2321 & 27 & EMP1 \\
\hline | & 2 & 1.0036 & 1 & .3165 & .5010 & .0349 & 28 & EMP2 \\
\hline | & 2 & .0000 & 1 & 1.0000 & .0014 & -1.4148 & 29 & EMP3 \\
\hline | & 2 & .0751 & 1 & .7840 & .0598 & -.8203 & 30 & EMP 4 \\
\hline | & 2 & .0784 & 1 & .7795 & .0644 & -.7995 & 31 & EMP5 \\
\hline
\end{tabular}

Pengujian menggunakan Differential Item Functional (DIF) plot dan nilai probabilitas tabel 30.4 pada Winstep, dimana perbedaan persepsi dinyatakan signifikan jika nilai $\mathrm{p}<0.05$, sebagaimana pada Gambar 3 dan Table 9, bahwa terdapat perbedaan persepsi mahasiswa di berbagai fakultas yang signifikan pada 9 butir, yaitu: TGL4 ( $p=0.0012)$, RLB1 $(p=0.0083)$, RLB2 ( $p=0.0017)$, RLB5 ( $p=0.0018)$, RSP1 (0.0000), RSP6 ( $p=0.0437)$, ASR1 $(p=0.0000)$, ASR2 $(p=0.0094)$ dan EMP5 $(p=0.0127)$. Ini berarti sembilan butir (item) tersebut harus diperbaiki karena masih mengandung bias berdasarkan fakultas.

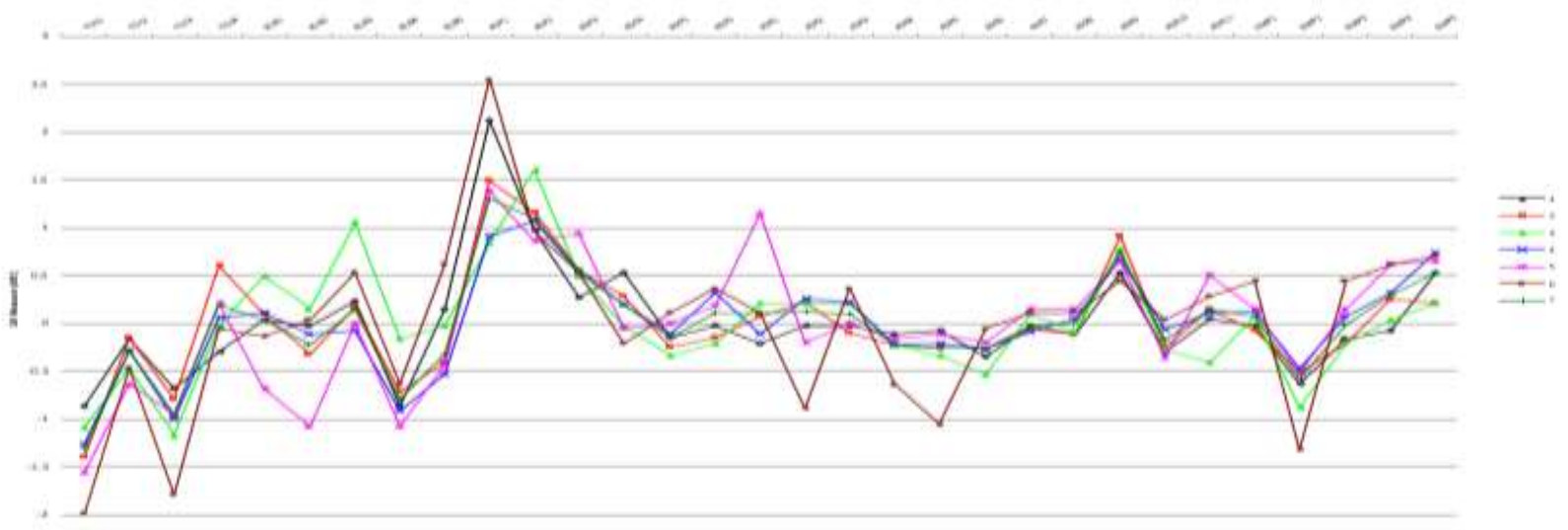

Gambar 3: Hasil Differential Item Functional (DIF) plot Berdasarkan Fakultas

Keterangan: Gambar 3: 1 = FMIPA; 2 = FKIP; $3=$ FISIB; $4=$ FE; $5=$ FH; $6=$ FT 
Tabel 7. Hasil Uji D.F Person Classes Berdasarkan Fakultas

\begin{tabular}{|c|c|c|c|c|c|c|c|c|}
\hline \multirow{2}{*}{$\begin{array}{ll}\text { | Person } \\
\text { | CLASSES }\end{array}$} & \multirow{2}{*}{$\begin{array}{l}\text { SUMMARY DIF } \\
\text { CHI-SQUARE }\end{array}$} & \multirow[b]{2}{*}{ D.F. } & \multirow[b]{2}{*}{ PROB. } & \multicolumn{2}{|c|}{ BETWEEN-CLASS } & \multicolumn{2}{|l|}{ Item } & \multirow{2}{*}{ । } \\
\hline & & & & MEAN-SQUARE & $\mathrm{t}=\mathrm{ZSTD}$ & Number & Name & \\
\hline & & & & & & & & \\
\hline 6 & 10.1111 & 5 & .0720 & .2041 & -1.7396 & 1 & TGL1 & । \\
\hline 6 & 5.4154 & 5 & .3670 & .1576 & -1.9703 & 2 & TGL2 & । \\
\hline 6 & 10.0375 & 5 & .0740 & .2240 & -1.6517 & 3 & TGL3 & । \\
\hline 6 & 20.1539 & 5 & .0012 & .9538 & .1366 & 4 & TGL4 & । \\
\hline 6 & 15.5382 & 5 & .0083 & .3867 & -1.0769 & 5 & RLB1 & । \\
\hline 6 & 19.3237 & 5 & .0017 & .5349 & -.6822 & 6 & RLB2 & । \\
\hline 6 & 19.0970 & 5 & .0018 & .6045 & -.5218 & 7 & RLB3 & । \\
\hline 6 & 9.7408 & 5 & .0827 & .2518 & -1.5373 & 8 & RLB 4 & । \\
\hline 6 & 19.1325 & 5 & .0018 & .5755 & -.5870 & 9 & RLB5 & । \\
\hline 6 & 46.2855 & 5 & .0000 & 1.9133 & 1.3561 & 10 & RSP1 & । \\
\hline 6 & 6.7106 & 5 & .2428 & .1266 & -2.1507 & 11 & RSP2 & I \\
\hline 6 & 5.8067 & 5 & .3252 & .1277 & -2.1438 & 12 & RSP3 & I \\
\hline 6 & 7.2724 & 5 & .2009 & .1453 & -2.0391 & 13 & RSP 4 & I \\
\hline 6 & 2.6606 & 5 & .7520 & .0743 & -2.5387 & 14 & RSP 5 & I \\
\hline 6 & 11.4126 & 5 & .0437 & .6261 & -.4746 & 15 & RSP 6 & I \\
\hline 6 & 30.3347 & 5 & .0000 & 1.0801 & .3342 & 16 & ASR1 & I \\
\hline 6 & 15.2401 & 5 & .0094 & .3973 & -1.0454 & 17 & ASR2 & | \\
\hline 6 & 5.6165 & 5 & .3450 & .2864 & -1.4059 & 18 & ASR3 & । \\
\hline 6 & 2.2276 & 5 & .8167 & .0296 & -3.0654 & 19 & ASR 4 & । \\
\hline 6 & 7.7081 & 5 & .1728 & .1153 & -2.2237 & 20 & ASR5 & । \\
\hline 6 & 1.8282 & 5 & .8723 & .0261 & -3.1247 & 21 & ASR 6 & I \\
\hline 6 & 1.6188 & 5 & .8989 & .0542 & -2.7375 & 22 & ASR7 & I \\
\hline 6 & 2.0872 & 5 & .8369 & .0791 & -2.4961 & 23 & ASR8 & I \\
\hline 6 & 5.0614 & 5 & .4081 & .2067 & -1.7281 & 24 & ASR9 & । \\
\hline 6 & 3.3650 & 5 & .6437 & .1511 & -2.0063 & 25 & ASR10 & I \\
\hline 6 & 8.3094 & 5 & .1397 & .1580 & -1.9685 & 26 & ASR11 & I \\
\hline 6 & 3.7065 & 5 & .5922 & .1281 & -2.1412 & 27 & EMP1 & । \\
\hline 6 & 7.8028 & 5 & .1672 & .1671 & -1.9202 & 28 & EMP2 & । \\
\hline 6 & 7.1052 & 5 & .2126 & .2432 & -1.5718 & 29 & EMP3 & । \\
\hline 6 & 8.1729 & 5 & .1467 & .1585 & -1.9656 & 30 & EMP 4 & | \\
\hline 6 & 14.5028 & 5 & .0127 & .8546 & -.0312 & 31 & EMP 5 & \\
\hline
\end{tabular}

Instrumen penelitian yang baik harus melalui uji terlebih dahulu (Brinkman, 2009), tujuanya agar instrument tersebut memenuhi syarat validitas (Ghazali, 2016). Valid berarti tingkat kepercayaan (Zohrabi, 2013). Valid berarti instrument yang digunakan memiliki kemampuan untuk mengukur apa yang akan diukur (Rahmawati, 2019). Instrument yang baik harus memenuhi beberapa kriteria validitas sehingga banyak istilah validitas instrument: validitas isi, validitas konstrak/bangun, validitas prediktif, validitas statistic/realibilitas (Baghaei, 2014). Jika peneliti menggunakan Model Rasch untuk menganalisis instrument penelitian, seperti halnya dalam penelitian ini, maka peneliti dapat menggunakan Model Rasch sebagai alternative (Zile-Tamsen, 2017). Selama ini pengujian validitas instrument menggunakan uji validitas Pearson Product Moment untuk instrumen non-test/kuesioner (Widi, 2011) dan uji Point Biserial untuk instrument test dan pilihan benar salah (Jesyca R.T. Muaju, Adi Setiawan, 2013). Penggunaan Model Rasch untuk pengujian validitas instrument hasilnya bisa lebih variatif karena validitas instrument bisa menggunakan berbagai kriteria (Othman, 2014). Penelitian ini jika menggunakan kriateria validitas OUTFIT MNSQ hasilnya 31 butir valid dan 1 butir tidak valid (RSP1); jika menggunakan OUTFIT Z-STANDARD hasilnya dari 8 butir valid dan 24 tidak valid; jika menggunakan kriateria validitas Point Measure Correlation hasilnya 32 butir valid; jika menggunakan item: dimensionaly untuk mengukur sejauh mana butir (item) dapat mengukur konstruk yang diukur, maka hasilnya beberapa butir harus diperbaiki karena terkosentrasi pada satu dimensi saja; dan jika menggunakan rating (partial -credit) scale test hasilnya semua butir (item) instumen memenuhi kriteria. Berdasarkan temuan ini terbukti bahwa kelebihan Rasch Model dalam menganalisis validitas instrument dapat dilakukan dari beberapa segi sehingga instrument yang dihasilkan dapat lebih dipercaya(Abdaziz, Jusoh, \& Amlus, 2014). Analisis validitas menggunakan Rasch Model dapat dikatakan lebih baik karena kekonsistennaya (Jusoh, 2018). Dengan demikian pemodelan Rasch dapat membantu untuk mengatasi pengukuran item (butir) dengan cara yang benar (Wu \& Adams, 2007). 
Selain memenuhi sayarat validitas (Takaki, Taniguchi, \& Fujii, 2014), sebuah instrument penelitian juga harus memenuhi syarat reliabilitas (Mohajan, 2017). Reliabilitas berarti instrument tersebut jika digunakan oleh peneliti lain akan memiliki hasil yang relative sama hasilnya (Ghazali, 2016). Keunggulan tes reliabilitas dalam Rasch model yaitu instrument bisa diketahui memiliki 3 reliabilitas, yaitu reliabilitas person, alpha cronbach, dan reliabilitas item/butir(Stef van Buuren, 2015). Pada penelitian ini menunjukan bahwa instrument kualitas layanan dosen memiliki reliabilitas yang tinggi yaitu reliabilitas person 0.97 , reliabilitas alpha cronbach 0.94 dan reliabilitas item/butir 0.98 . Koefisien reliabilitas di atas 0.9 menunjukan sangat baik sekali (Mohamad, Lisa, Sern, \& Mohd, 2015). Ini berarti instrument kualitas layanan ini jika digunakan oleh peneliti lain maka hasilnya akan relatif ajeg atau memiliki kemiripin hasil. Instrumen yang memiliki reliabilitas tinggi merupakan salah satu ciri instrumen yang baik (Mohajan, 2017).

Instrumen yang baik harus pula memiliki kemampuan untuk menjangkau semua aspek yang diukur (Loubser, Casteleijn, \& Bruce, 2015). Model Rasch merupakan aplikasi yang dapat digunakan untuk mengevaluasi apakah sebuah instrument memiliki kemampuan mengukur (construct validity) (Baghaei, 2014), karena Model Rasch mampu menunjukan butir (item) instrumen yang sulit disetujui/dikerjakan oleh responden (Abdaziz et al., 2014) sekaligus disandingkan kemampuan respondennya (Bambang Sumintono, 2015). Hasil penelitian ini menunjukan bahwa berdasar hasil analisis menggunakan item measure dan variable map serta melihat Standar Deviasi (S.D) diperoleh gambaran butir (item) yang paling sulit disetujui dan paling mudah disetujui oleh responden dan bagaimana sebaran butirnya. Penelitian ini menemukan 10 butir (item) yang sulit disetujui reponden, butir (item) terlalu menumpuk di tengah atau kurang menyebar sesuai dengan dengan responden (mahasiswa) dan range tingkat kesulitan butir (item) tidak beragam sehingga perlu diperbaiki. Analisis butir yang sulit dan bagaimana hubunganya dengan kemampuan responden merupakan ciri khas Model Rasch untuk mengembangkan instrument dengan lebih baik (Mohamad et al., 2015). Analisis butir intrumen yang dikaitkan dengan kemampuan respondenya sangat membatu pembuatan instrument yang menjangkau aspek yang mau diukur (Nurulhuda, Mohd, Fauzi, Yunus, \& Ismail, 2018).

Instrument yang baik harus pula menghindari butir (item) yang ambigu (Aguilar, Cortes, Guerrero, Herrera, \& Orozco, 2011). Instrument yang ambigu harus dihindari karena akan dimaknai secara berbeda sehingga hasilnya pun berbeda (Josephine \& Mitan, 2014), banyak cara agar instrument terhindar dari ambigu (Bors, Gruman, \& Shukla, 2010), penggunaan model Rasch secara baik dapat membantu agar terhindar dari instrument yang ambigu atau tidak mampu dipahami dengan baik oleh responden (Siti Eshah Mokshein, 2019). Dalam penelitian ini Model Rasch menunjukan bahwa: terdapat 7 butir instrument dipersepsikan secara berbeda dengan signifikan oleh responden (mahasiswa) laki-laki dan perempuan; dan terdapat 9 butir instrument yang dipersepsikan berbeda dengan signifikan oleh mahasiswa dari fakultas yang berbeda-beda. Jika ditemukan butir instrument yang dipersepsikan berbeda, maka butir intrumen itu harus diperbaiki (Wibisono, 2014).

\section{Kesimpulan}

Instrumen kualitas layanan dosen yang memiliki validas dan reliabilitas tinggi sangat dibutuhkan untk penelitian yang bertujuan meningkatkan kualitas layanan pada mahasiswa. Instrumen kualitas layanan yang diperoleh dalam penelitian ini berasal dari sebuah proses penelitian mulai dari tinjauan literatur, wawancara, validasi ahli dan analisis data menggunakan pemodelan Rasch. Berdasarkan hasil pengujian menggunakan Model Rasch ditemukan 31 butir instrument kualitas layanan dosen yang valid dan satu butir yang tidak valid sehingga harus dibuang. Berdasarkan uji uji reliabilitas menggunajan analysis Model rasch ditemukan bahwa instrument kualitas layanan dosen ini sangat terpercaya karena memiliki nilai reliabilitas di atas 0.9 , baik dari segi reliabilitas person, alpha cronbach maupun reliabilitas butir (items). Namun demikian berdasarkan uji tingkat kesukaran butir menggunakan item measure, item dimensionality dan variable map serta uji Item: DIF ditemukan beberapa butir (item) yang harus diperbaiki karena masih mengandung bias (gender dan fakultas) dan kurang mampu menjangkau range variabel yang diteliti .

\section{Referensi}

Abdaziz, A., Jusoh, M. S., \& Amlus, H. (2014). Construct Validity: A Rasch Measurement Model Approaches. Journal of Applied Science and Agriculture, 9 (September), 7-12.

Abdullah, N., \& Mohamad, N. (2016). University Recreational Facilities Service Quality and Students ' Physical Activity Level. Procedia - Social and Behavioral Sciences, 224(August 2015), 207-212. https://doi.org/10.1016/j.sbspro.2016.05.443 
Aguilar, H. C., Cortes, P. P., Guerrero, A. V, Herrera, C. D. C., \& Orozco, J. A. T. (2011). Construction and Validation of an Instrument To Evaluate Critical Reading of Research Papers. 2011 4th International Conference of Education, Research and Innovation, (November), 5286-5294.

Azam, A. (2018). Service Quality Dimensions and Students ' Satisfaction : A study of Saudi Arabian Private Higher Education Institutions. European Online Journal of Natural and Social Sciences, 7(2), 275-284.

Baghaei, P. (2014). The Rasch Model as a Construct Validation Tool. Rasch Measurement Transactions, 22(1).

Bambang Sumintono, W. W. (2014). Aplikasi Model Rasch Untuk Penelitian Ilmu-Ilmu Sosial. Cimahi: Trim Komunikata.

Bambang Sumintono, W. W. (2015). Aplikasi Pemodelan Rasch pada Asesment Pendidikan. Cimahi: Trim Komunikata.

Bond, T. G., \& Fox, C. M. (2007). Applying the Rasch Model: Fundamental Measurement in the Human Sciences Second Edition University of Toledo. New Jersey 07430: Lawrence Erlbaum Associates, Inc.

Boon, T., Shukur, M., \& Bassim, A. (2016). Evaluation of Service Quality of Private Higher Education using Service Improvement Matrix. Procedia - Social and Behavioral Sciences, 224(August 2015), 132-140. https://doi.org/10.1016/j.sbspro.2016.05.417

Bors, D. A., Gruman, J. A., \& Shukla, S. (2010). Measuring tolerance of ambiguity: Item polarity , dimensionality, and criterion validity. Revue Europeenne de Psychologie Appliquee, 60(4), 239-245. https://doi.org/10.1016/j.erap.2010.07.001

Brinkman, W.-P. (2009). Design of a Questionnaire Instrument. Handbook of Mobile Technology Research Methods, (December), 31-57.

Carvalho, L. D. F., Primi, R., \& Meyer, G. J. (2012). Application of the Rasch model in measuring personality disorders. Trends, 34(2), 101-109.

Deb, S., \& Ahmed, M. A. (2018). Determining the service quality of the city bus service based on users ' perceptions and expectations. Travel Behaviour and Society, 12(February), 1-10. https://doi.org/10.1016/j.tbs.2018.02.008

Dursun, T., Oskayba, K., \& Gökmen, C. (2013). The Quality Of Service Of The Distance Education. In 13th International Educational Technology Conference The (Vol. 103, pp. 1133-1151). https://doi.org/10.1016/j.sbspro.2013.10.441

Esmaeilpour, M., \& Ranjbar, M. (2016). Investigating the Impact of Commitment, Satisfaction, and Loyalty of Employees on Providing High - Quality Service To Customer. Journal of Modelling in Management, 14(3), 355-388.

Ghazali, N. H. M. (2016). A Reliability and Validity of an Instrument to Evaluate the School-Based Assessment System : A Pilot Study. International Journal of Evaluation and Research in Education (IJERE), 5(2), 148-157.

Hendriks, J., Fyfe, S., Styles, I., Skinner, S. R., Merriman, G., \& Hendriks, J. (2012). Scale construction utilising the Rasch unidimensional measurement model: A measurement of adolescent attitudes towards abortion. Australasian Medical Journal [AMJ 2012, 5(5), 251-261.

Jesyca R.T. Muaju, Adi Setiawan, T. M. (2013). Uji Validitas dan Reliabilitas Menggunakan Metode Boostrap pada Kuisioner Ripe Yes/No Questions. In Prosiding Seminar Nasional Sains dan Pendidikan Sains VII (p. 513).

Jiao, H., Lissitz, R. W., \& Macready, G. (2011). Exploring levels of performance using the mixture Rasch model for standard setting 1, 53(4), 499-522.

John 1. Pollock. (1967). Logical validity in modal logic. The Monist, 51(1), 128-135.

Josephine, H., \& Mitan, C. (2014). Studi Eksperimental : Mengurangi Bias Pengukuran Umum Balanced Scorecard dalam Penilaian Kinerja pada Mahasiswa S1 Program Akuntansi Pajak. BUSINESS ACCOUNTING REVIEW, 2(2), 32-41.

Jusoh. (2018). Construct Validity for Measuring Entrepreneurial Readiness Among Malaysian Higher Education Students : A Stochastic Measurement Model Approach. In MATEC Web of Conferences 150, (Vol. 150, pp. 1-4).

Klette, K. (2012). Mixed Methods in Educational Research. Oslo: The Research Council of Norway.

Kumar, S., Shekhar, V., Lassar, W. M., \& Chen, T. (2018). Journal of Retailing and Consumer Services Customer engagement behaviors: The role of service convenience, fairness and quality. Journal of Retailing and Consumer Services, 44(December 2017), 293-304. https://doi.org/10.1016/j.jretconser.2018.07.018

Linacre, J. M. (2010). Predicting Responses from Rasch Measures. JOURNAL OF APPLIED MEASUREMENT, 11(1), 1-10.

Loubser, H. J., Casteleijn, D., \& Bruce, J. C. (2015). ScienceDirect The BETA ${ }^{\circledR}$ nursing measure: Calibrating construct validity with Rasch analyses. Health SA Gesondheid, 20(1), 22-32. 
https://doi.org/10.1016/j.hsag.2015.02.001

Meerah, T. S. M., Osman, K., Zakaria, E., \& Ikhsan, Z. H. (2012). Developing an Instrument to Measure Research Skills. Procedia - Social and Behavioral Sciences, 60, 630-636. https://doi.org/10.1016/j.sbspro.2012.09.434

Mohajan, H. K. (2017). Two Criteria for Good Measurements in Research: Validity and Reliability. Annals of Spiru Haret University, 17(3), 1-32.

Mohamad, M. M., Lisa, N., Sern, L. C., \& Mohd, K. (2015). Measuring the Validity and Reliability of Research Instruments. Procedia - Social and Behavioral Sciences, 204(November 2014), 164-171. https://doi.org/10.1016/j.sbspro.2015.08.129

NGUYEN THANH DONG, D. N. F. S. (2014). Applying the Rasch Model to Investigate Singapore Principals ' Instructional Leadership Practices. Leading \& Managing, 20(2), 1-26.

Nurulhuda, S., Mohd, T., Fauzi, M., Yunus, M., \& Ismail, I. (2018). The use of rasch measurement model for the validity and reliability. Journal of Counseling and Educational Technology, 1(2), 22-27.

Oriade, A., \& Scho, P. (2019). An examination of the role of service quality and perceived value in visitor attraction experience. Journal of Destination Marketing \& Management, 11(May 2018), 1-9. https://doi.org/10.1016/j.jdmm.2018.10.002

Othman, N. B. (2014). Assessing Construct Validity and Reliability Of Competitiveness Scale Using Rasch Model Approach. In The 2014 WEI International Academic Conference Proceedings (pp. 113-120).

Prentice, C., \& Kadan, M. (2019). Journal of Retailing and Consumer Services The role of airport service quality in airport and destination choice. Journal of Retailing and Consumer Services, 47(July 2018), 40 48. https://doi.org/10.1016/j.jretconser.2018.10.006

Rahmawati, E. (2019). Developing instruments of teacher' s perception of critical thinking in elementary school. Journal of Education and Learning (EduLearn), 13(4), 559-566. https://doi.org/10.11591/edulearn.v13i4.13232

Rajab, A., Aishah, S., Rahman, A., Abdul, H., Shaari, R., \& Saat, M. (2011). Service Quality in a Research University: A Post-Graduate Perspective. Procedia - Social and Behavioral Sciences, 29, 1830-1838. https://doi.org/10.1016/j.sbspro.2011.11.431

Roy, S. (2019). Service quality versus service experience : An empirical examination of the consequential e ff ects in B2B services. Industrial Marketing Management, $X X X$ (February 2017). https://doi.org/10.1016/j.indmarman.2019.02.017

Siti Eshah Mokshein, H. I. and H. A. (2019). The Use of Rasch Measurement Model In English Testing. Cakrawala Pendidikan, 38(1), 16-32. https://doi.org/10.21831/cp.v38i1.22750

Stef van Buuren, D. J. D. W. (2015). Measuring Psychosocial Impact of CBRN Incidents by the Rasch Model. JOURNAL OF APPLIED MEASUREMENT, 16(3).

Stefan, C. (2010). The quality consulting services management in the university educational system. Procedia - Social and Behavioral Sciences, 2(2), 5586-5589. https://doi.org/10.1016/j.sbspro.2010.03.911

Sugiyono. (2015). Metode Penelitian Kombinasi (Mix Methods). Bandung: Alfabeta.

Takaki, J., Taniguchi, T., \& Fujii, Y. (2014). Reliability , Validity , and Significance of Assessment of Sense of Contribution in the Workplace. International Journal of Environmental Research and Public Health, 11, 1594-1604. https://doi.org/10.3390/ijerph110201594

Tesio, Il. (2003). MEASURING BEHAVIOURS AND PERCEPTIONS : RASCH ANALYSIS AS A TOOL FOR REHABILITATION RESEARCH. J Rehabil Med, 35, 105-115.

Wibisono, S. (2014). APLIKASI MODEL RASCH UNTUK VALIDASI FUNDAMENTALISME AGAMA BAGI RESPONDEN MUSLIM Susilo Wibisono. Jurnal Pengukuran Psikologi Dan Pendidikan Indonesia, III(3), $730-750$.

Widi, R. (2011). Uji Validitas dan Reliabilitas dalam Penelitian Epidemiologi Kedokteran Gigi. Stomatognatic (J.K.G. Unej) Vol., 8(1), 27-34.

Wu, M., \& Adams, R. (2007). Applying The Rasch Model To Psycho-Social Measurement A Practical Approach. Melbourne.: Educational Measurement Solutions.

Zile-Tamsen, C. Van. (2017). Using Rasch Analysis to Inform Rating Scale. Research in Higher Education. https://doi.org/10.1007/s11162-017-9448-0

Zohrabi, M. (2013). Mixed Method Research: Instruments, Validity, Reliability and Reporting Findings. Theory and Practice in Language Studies, 3(2), 254-262. https://doi.org/10.4304/tpls.3.2.254-262 